\title{
Perioperative blood transfusion is associated with a gene transcription profile characteristic of immunosuppression: a prospective cohort study
}

Paraskevi C Fragkou ${ }^{1,2 \dagger}$, Hew D Torrance ${ }^{1,2 \dagger}$, Rupert M Pearse ${ }^{1,2}$, Gareth L Ackland ${ }^{3}$, John R Prowle ${ }^{1}$, Helen C Owen ${ }^{2}$, Charles J Hinds ${ }^{1,2}$ and Michael J O'Dwyer ${ }^{1,2^{*}}$

\begin{abstract}
Introduction: Blood transfusion in the perioperative period has frequently been associated with an excess of nosocomial infections. Whilst transfused whole blood induces specific host immune alteration that may predispose to nosocomial infections, the immunomodulating properties associated with leukodepleted blood remain incompletely understood. In this study, we explore the hypothesis that the transfusion of leukodepleted allogeneic blood during or following major gastrointestinal surgery is associated with an immunosuppressed phenotype, which may in turn predispose to postoperative infectious complications.
\end{abstract}

Methods: Patients aged over 45 years undergoing scheduled inpatient major gastrointestinal surgery were recruited. Gene expression profiles of specific inflammatory genes were assayed from blood collected preoperatively, at 24 and at 48 hours after surgery. Genes were selected based on their ability to represent specific immune pathways. Gene expression was quantified using quantitative real-time polymerase chain reaction (qRT-PCR) to measure messenger RNA (mRNA) levels. Postoperative infections were documented using predefined criteria.

Results: One hundred and nineteen patients were recruited. Fifteen (13\%) patients required blood transfusion within 24 hours of surgery, 44 (37\%) patients developed infections and $3(2 \%)$ patients died prior to discharge. Patients receiving a blood transfusion were more likely to develop postoperative infections $(P=0.02)$ and to have lower tumour necrosis factor alpha (TNFa), interleukin (IL)-12, IL-23 and RAR-related orphan receptor gamma T (RORyt) gene expression in the postoperative period $(P<0.05)$. The TNFa/IL-10 mRNA ratio at 24 hours $(P=0.0006)$ and at 48 hours $(P=0.01)$ was lower in patients receiving a blood transfusion over this period. Multivariable analysis confirmed that these observations were independent of the severity of the surgical insult.

Conclusions: An association between an immunosuppressive pattern of gene expression and blood transfusion following major elective gastrointestinal surgery is described. This gene expression profile includes a reduction in the activity of innate immunity and T helper cell type $1\left(T_{h} 1\right)$ and T helper cell type $17\left(T_{h} 17\right)$ pathways in those patients receiving a blood transfusion. Blood transfusion was also associated with an excess of infectious complications in this cohort. A mechanistic link is suggested but not proven.

\footnotetext{
* Correspondence: michael.odwyer@bartshealth.nhs.uk

${ }^{\dagger}$ Equal contributors

${ }^{1}$ Adult Critical Care Unit, Royal London Hospital, Barts Health NHS Trust, Whitechapel Road, London E1 1BB, UK

${ }^{2}$ Centre for Translational Medicine and Therapeutics, William Harvey Research Institute, Barts and the London School of Medicine and Dentistry, Queen Mary University of London, Charterhouse Square, London EC1M 6BQ, UK Full list of author information is available at the end of the article
}

\section{Biomed Central}

(c) 2014 Fragkou et al.; licensee BioMed Central Ltd. This is an Open Access article distributed under the terms of the Creative Commons Attribution License (http://creativecommons.org/licenses/by/4.0), which permits unrestricted use, distribution, and reproduction in any medium, provided the original work is properly credited. The Creative Commons Public Domain Dedication waiver (http://creativecommons.org/publicdomain/zero/1.0/) applies to the data made available in this article, unless otherwise stated. 


\section{Introduction}

The immunomodulating qualities of allogenic blood transfusion have long been appreciated and have even been exploited to prevent renal allograft rejection in the era prior to the development of effective immunosuppressant drugs [1]. The unintended clinical consequences of immune modulation by allogenic blood in the perioperative period include an increased susceptibility to infectious complications and cancer recurrence [2,3]. As inpatient non-cardiac surgery has recently been associated with much higher than anticipated mortality rates, it is now imperative that all potentially avoidable causes of excess morbidity in this population are investigated and addressed [4]. Whilst preoperative anaemia is associated with a doubling of inhospital mortality, it remains unclear whether the anaemia itself or its treatment with allogeneic blood is responsible [5]. Furthermore, perioperative blood transfusions are not universally associated with an increase in complications particularly when patients receiving leukodepleted blood are included [2,6]. Also lacking from the current literature is an analysis of alterations in key inflammatory pathways associated with the transfusion of leukodepleted blood following major elective surgery, although our group has recently described an association between blood transfusion following severe traumatic injury, an anti-inflammatory pattern of gene expression and an excess of infectious complications [7].

It has been repeatedly demonstrated that messenger RNA (mRNA), assayed using real-time polymerase chain reaction (RT-PCR), can be used to accurately quantify patterns of gene expression [8-10]. Furthermore, careful selection of key regulatory and effector cytokines in conjunction with transcription factors specific to $\mathrm{T}$ cell subtypes allow inferences to be made as to the activity of specific inflammatory pathways related to T-helper $\left(\mathrm{T}_{h}\right)$ cell development [11]. For example, an analysis that combines gene expression data relating to the key $T_{h} 1$-promoting cytokine, interleukin (IL)-12, the main $T_{h} 1$ effector cytokine, interferon gamma (IFN $\gamma$ ) and the $\mathrm{T}_{\mathrm{h}} 1$-specific transcription factor T-bet may be descriptive of the general activity of the $\mathrm{T}_{\mathrm{h}} 1$ pathway. A similar approach can aid in the description of T-helper cell type $2\left(\mathrm{~T}_{h} 2\right), \mathrm{T}_{\mathrm{h}} 17$ and $\mathrm{T}$ regulatory $\left(\mathrm{T}_{\text {reg }}\right)$ cell pathways. This methodology has been previously utilised to predict perioperative infectious complications based on alterations in T cell pathways [10].

In this study, we explore the hypothesis that blood transfusion during and following major elective gastrointestinal surgery is associated with an immunosuppressive pattern of gene expression, which may enhance susceptibility to later infectious complications.

\section{Methods}

This prospective cohort study was conducted at The Royal London Hospital, London UK and University College
Hospital, London between June 2012 and November 2013. Ethical approval was granted by the North Wales Ethics Committee (Reference: 10/WNo03/25) and this research was conducted in compliance with the Helsinki Declaration. Each patient on a weekday elective operating list was screened. Eligible patients were then approached for written informed consent. Entry into the study did not influence the patient's clinical treatment course in any way. In our institution, scheduled postoperative intensive care unit (ICU) admission is mandated for specific surgical procedures. Based on an individual patient's co-morbidities the surgical or anaesthesia teams may also request postoperative ICU treatment. All patients received perioperative prophylactic antibiotic treatment as outlined in Additional file 1.

\section{Patient selection}

Patients aged over 45 years undergoing scheduled surgery involving the gastrointestinal tract, requiring a general anaesthetic and at least an overnight hospital stay were considered eligible for inclusion to this study. Exclusion criteria were emergency surgery and surgery that also involved access to the thoracic cavity.

\section{Data collection}

Data were collected on each patient until hospital discharge and included information on co-morbidities, American Society of Anesthesiology (ASA) physical status classification [12] indication for surgery, cancer diagnosis, duration of the procedure, planned postoperative ICU admission and inhospital mortality. Preoperative immunosuppression was defined as the administration of chemotherapeutic agents and/or radiotherapy within the six months preceding surgery. The timing of any blood products administered was recorded for each patient during the first 24 hours. All packed red blood cells (PRBC) administered were leukocyte depleted prior to storage, included a standard sodium chloride, adenine, glucose, mannitol (SAGM) additive solution and had a maximum age of 35 days. Patients were examined daily by the clinical team for the presence of infection, which was then recorded by the research team following discussions with ICU physicians, surgeons or microbiologists where necessary. Definitions of infection were agreed prospectively by the investigators and were based on the Center for Disease Control and Prevention definitions and graded using the Clavien-Dindo classification (see Additional file 2) [13].

\section{Blood sampling and laboratory techniques}

Blood samples were taken immediately before induction of anaesthesia ( 0 hours), at 24 and 48 hours following the operation. At each time point blood was collected in a PAXGene ${ }^{\mathrm{Tn}}$ blood RNA tube (PreAnalytix, Hilden, Germany). Total RNA was extracted using PAXGene ${ }^{\mathrm{m} t}$ 
blood RNA kit (PreAnalytix). Samples were analysed for their integrity and reverse transcribed to complementary DNA (cDNA) [11]. Genes were selected to reflect key elements of specific immune pathways (Table 1). Gene expression was quantified using quantitative real-time polymerase chain reaction (qRT-PCR). qRT-PCRs were performed using Taqman assays (Applied Biosystems, Foster City, CA, USA), which spanned the final two exons of the most common isoform of each gene, and were carried out on a 7900HT, Life Tech (Applied Biosystems, Foster City, CA, USA) as previously described [7]. Each sample was assayed in triplicate. Reference genes ( $\beta 2 \mathrm{mi}-$ croglobulin $(B 2 M)$ and ubiquitin $C(U B C)$ ) were selected empirically from a panel of six [14]. Relative quantification was calculated using the standard delta delta methodology [15]. Results were expressed as a normalized ratio of candidate gene/reference gene.

\section{Statistical analysis}

Results are expressed as median and interquartile range (IQR) or odds ratios (OR) with 95\% confidence intervals

Table 1 Selected cytokines and transcription factors and their related pathways

\begin{tabular}{|c|c|c|}
\hline Gene & Immune pathway & $\begin{array}{c}\text { Contributes to anti (-) or } \\
\text { pro (+) inflammatory } \\
\text { phenotype }{ }^{a}\end{array}$ \\
\hline$\overline{\mathrm{TNFa}(T N F)^{\mathrm{b}}}$ & $\begin{array}{l}\text { Common end product of } \\
\text { many innate and adaptive } \\
\text { immune pathways }\end{array}$ & + \\
\hline IFNy $(I F N G)^{\mathrm{b}}$ & $T_{h} 1$ effector cytokine & + \\
\hline $\mathrm{IL}-12(\operatorname{IL} 12 \mathrm{~A})^{\mathrm{b}}$ & $\begin{array}{l}\text { Promotes differentiation } \\
\text { to } T_{h} 1 \text { effector cells }\end{array}$ & + \\
\hline T-bet $(T B \times 21)^{b}$ & $\begin{array}{l}\text { Transcription factor utilised } \\
\text { by } T_{h} 1 \text { cells }\end{array}$ & + \\
\hline $\mathrm{IL}-23(\operatorname{IL} 23 A)^{\mathrm{b}}$ & $\begin{array}{l}\text { Promotes differentiation } \\
\text { to } T_{h} 17 \text { phenotype }\end{array}$ & + \\
\hline IL-27 (IL27) $)^{\mathrm{b}}$ & $\begin{array}{l}\text { Inhibits differentiation } \\
\text { to } T_{h} 17 \text { phenotype }\end{array}$ & - \\
\hline RORYT $(R O R C)^{b}$ & $\begin{array}{l}\text { Transcription factor utilised } \\
\text { by } T_{h} 17 \text { cells }\end{array}$ & + \\
\hline $\operatorname{IL}-10(/ L 10)^{b}$ & $\begin{array}{l}\text { Anti-inflammatory cytokine } \\
\text { produced by many T cell } \\
\text { subtypes and some } \\
\text { macrophages }\end{array}$ & - \\
\hline Foxp3 (FOXP3) & $\begin{array}{l}\text { Transcription factor utilised } \\
\text { by naturally occurring CD4 } \\
\text { CD } 25^{+} \mathrm{T}_{\text {reg }} \text { cells }\end{array}$ & - \\
\hline GATA3 $(\text { GATA3) })^{b}$ & $\begin{array}{l}\text { Transcription factor utilised } \\
\text { by } T_{h} 2 \text { cells }\end{array}$ & - \\
\hline
\end{tabular}

${ }^{a}$ Cytokines and transcription factors will have diverse actions under different conditions and the descriptions above are primarily for illustrative purposes and are not exhaustive; ${ }^{b}$ denotes official gene name as described by the HUGO Gene Nomenclature Committee (HGNC). Foxp3, forkhead box P3; GATA3, GATA-binding protein 3; IFN $\gamma$, interferon gamma; IL-12, interleukin 12 IL-23, interleukin 23; IL-27, interleukin 27; RORyt, RAR-related orphan receptor gamma $T_{;} T_{h} 1$, T-helper cell type $1 ; T_{h} 17$, T-helper cell type $17 ; T_{h} 2, T$-helper cell type 2; TNFa, tumour necrosis factor alpha; $\mathrm{T}_{\text {reg, }} \mathrm{T}$ regulatory cell.
(CI). All statistical tests are two-sided and a $P$ value of $P<0.05$ was considered significant. Differences in categorical variables were calculated using a chi-squared or Fisher's exact test as appropriate. The Kruskal-Wallis test was utilised for continuous variables.

Multivariable linear regression models assessed whether gene expression was independently associated with blood transfusion. A model was constructed in each case where gene expression was demonstrated to be associated with blood transfusion on a univariate analysis. Gene expression was then selected as the dependent variable following $\log$ transformation of the mRNA levels. A univariate analysis then assessed the relationship between gene expression and age, sex, duration of operation, ASA physical status classification, cancer diagnosis and preoperative immunosuppression. If this univariate analysis demonstrated a $P$ value $<0.1$ then that variable was added to the above model as an independent variable. Backwards elimination on non-significant variables was performed when appropriate (see Additional file 3).

A multivariable logistical regression analysis assessed whether infectious complications were independently associated with blood transfusion. The occurrence of infectious complications was the dependent variable and the threshold for inclusion of other variables was again $P<0.1$, with variables selected from Table 2 (see Additional file 4).

Data analysis was performed using the JMP (version 11) statistical software package (SAS Institute Inc., Cary, NC, USA).

\section{Results \\ Patients}

A total of 119 patients (mean age 65, range 57 to 72 , $62 \%$ male) undergoing elective major abdominal surgery were included in this study. Fifteen (13\%) patients received a blood transfusion. Forty-four (37\%) patients developed a postoperative infection. Three $(2.5 \%)$ patients died prior to hospital discharge. Patient characteristics are shown in Tables 2 and 3.

\section{Blood transfusion}

In total $15(13 \%)$ patients were transfused over the 24 hours following the commencement of surgery. The median number of units of PRBCs transfused in this group was 2 (IQR 1 to 2). Ten of these 15 patients received an intraoperative transfusion, 8 of these 15 received their transfusion in the postoperative period and, therefore, 3 of the 15 patients received a transfusion both intraoperatively and postoperatively. No other blood product was transfused during this time period. Older patients $(P=0.0002)$ and those with a diagnosis of cancer $(P=0.02)$ were more likely to receive PRBC transfusions. Smokers were less likely to receive a blood transfusion $(P=0.04)$. 
Table 2 Characteristics of patients developing infections and those remaining infection-free following scheduled abdominal surgery

\begin{tabular}{|c|c|c|c|}
\hline & $\begin{array}{l}\text { Infection, } \\
\mathrm{n}=44(37 \%)\end{array}$ & $\begin{array}{l}\text { Infection-free, } \\
\mathrm{n}=75(63 \%)\end{array}$ & $P$ value \\
\hline Age (years) & $66(59-75)$ & $64(56-71)$ & 0.19 \\
\hline Male sex (\%) & 61 & 63 & $>0.99$ \\
\hline Diabetes (\%) & 18 & 16 & 0.80 \\
\hline Current smokers (\%) & 23 & 19 & 0.64 \\
\hline Smoking history (\%) & 48 & 57 & 0.34 \\
\hline Cancer diagnosis (\%) & 55 & 71 & 0.10 \\
\hline $\begin{array}{l}\text { Preoperative } \\
\text { immunosuppression (\%) }\end{array}$ & 14 & 14 & $>0.99$ \\
\hline $\begin{array}{l}\text { Duration of operation } \\
\text { (minutes) }\end{array}$ & $243(176-313)$ & $195(142-295)$ & 0.06 \\
\hline Endoscopic surgery (\%) & 18 & 32 & 0.13 \\
\hline $\begin{array}{l}\text { Planned postoperative } \\
\text { intensive care unit } \\
\text { admission (\%) }\end{array}$ & 77 & 66 & 0.22 \\
\hline ASA grade 3 or $4(\%)$ & 30 & 31 & $>0.99$ \\
\hline \multicolumn{4}{|l|}{ By surgical specialty n (\%) } \\
\hline General surgery & $4(44)$ & $5(55)$ & \\
\hline Upper gastrointestinal & $9(33)$ & $18(67)$ & \\
\hline Colorectal & $18(37)$ & $31(63)$ & \\
\hline HPB & $11(37)$ & $19(63)$ & \\
\hline HPB + colorectal & $1(33)$ & $2(67)$ & \\
\hline General surgery + colorectal & $1(100)$ & $0(0)$ & $0.84^{\mathrm{a}}$ \\
\hline $\begin{array}{l}\text { Intraoperative blood } \\
\text { transfusion (\%) }\end{array}$ & 14 & 5 & 0.17 \\
\hline $\begin{array}{l}\text { Blood transfusion in the } \\
\text { first } 24 \text { hours (\%) }\end{array}$ & 23 & 7 & 0.02 \\
\hline Inhospital death n (\%) & $1(2 \%)$ & $2(2.5 \%)$ & $>0.99$ \\
\hline
\end{tabular}

Data are described as medians with interquartile range or numbers with percentages in parenthesis. mRNA levels are expressed as a relative quantification

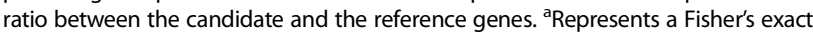
test incorporating all surgical specialties. ASA, American Society of

Anesthesiology; HPB, Hepato-Pancreato-Biliary.

The requirement for blood transfusion was not related to the duration of the operation, whether the procedure was endoscopic or open or the ASA grade (Table 3). Patients receiving $\mathrm{PRBC}$ transfusions were more likely to develop postoperative infections (OR 5.5 (1.3 to 12.8); $P=0.02$ (Fisher's exact test), Figure 1A) and were more likely to die inhospital (OR 15.7 (1.3 to 185.3); $P=0.04$ (Fisher's exact test), Figure 1B).

\section{Blood transfusion and gene expression}

On univariate analysis, IL-12 mRNA levels at 24 hours $(P=0.02)$ and tumour necrosis factor alpha (TNF $\alpha)$ mRNA levels at 48 hours $(P=0.01)$ were lower in those who received a blood transfusion in the first 24 hours postoperatively. IL-23 mRNA levels at 24 hours $(P=0.007)$
Table 3 Characteristics of patients requiring perioperative blood transfusion following scheduled abdominal surgery

\begin{tabular}{llll}
\hline & $\begin{array}{l}\text { Transfused, } \\
\mathbf{n = 1 5}(\mathbf{1 3 \% )}\end{array}$ & $\begin{array}{l}\text { Not transfused, } \\
\mathbf{n = 1 0 3}(\mathbf{8 7} \%)\end{array}$ & $\boldsymbol{P}$ value \\
\hline Age (years) & $77(72-81)$ & $63(56-70)$ & 0.0002 \\
Male sex (\%) & 60 & 62 & 1.0 \\
Diabetes (\%) & 20 & 17 & 0.72 \\
Current smokers (\%) & 0 & 23 & 0.04 \\
Smoking history (\%) & 27 & 58 & 0.02 \\
Cancer diagnosis (\%) & 93 & 60 & 0.02 \\
$\begin{array}{l}\text { Preoperative } \\
\text { immunosuppression (\%) }\end{array}$ & 29 & 12 & 0.10 \\
$\begin{array}{l}\text { Duration of operation } \\
\text { (minutes) }\end{array}$ & $240(150-400)$ & $212(145-296)$ & 0.26 \\
$\begin{array}{l}\text { Endoscopic surgery (\%) } \\
\text { Planned postoperative }\end{array}$ & 13 & 29 & 0.35 \\
intensive care unit & & 68 & 0.22 \\
$\begin{array}{l}\text { admission (\%) } \\
\text { ASA grade 3 or 4 (\%) }\end{array}$ & 50 & & 0.18
\end{tabular}

By surgical specialty $\mathbf{n}(\%)$

\begin{tabular}{|c|c|c|c|}
\hline General surgery & $0(0)$ & $8(7)$ & \\
\hline Upper gastrointestinal & $4(27)$ & $23(22)$ & \\
\hline Colorectal & $5(33)$ & $44(43)$ & \\
\hline $\mathrm{HPB}$ & $5(33)$ & $25(24)$ & \\
\hline HPB + colorectal & $1(7)$ & $2(2)$ & \\
\hline $\begin{array}{l}\text { General surgery + } \\
\text { colorectal }\end{array}$ & $0(0)$ & $1(1)$ & $0.65^{a}$ \\
\hline $\begin{array}{l}\text { Postoperative } \\
\text { infections n (\%) }\end{array}$ & $10(66 \%)$ & $34(33 \%)$ & 0.02 \\
\hline Inhospital death n (\%) & $2(13 \%)$ & $1(1 \%)$ & 0.04 \\
\hline
\end{tabular}

Data are described as medians with interquartile range or numbers with percentages in parenthesis. mRNA levels are expressed as a relative quantification ratio between the candidate and the reference genes. ${ }^{a}$ Represents a Fisher's exact test incorporating all surgical specialties. ASA, American Society of Anesthesiology; HPB, Hepato-Pancreato-Biliary.

and at 48 hours $(P=0.03)$ and RAR-related orphan receptor gamma $\mathrm{T}(\mathrm{ROR} \gamma \mathrm{t})$ mRNA levels at 24 hours $(P=0.004)$ and at 48 hours $(P=0.006)$ were lower in those receiving a blood transfusion over the first 24 hours postoperatively. The TNF $\alpha / \mathrm{IL}-10 \mathrm{mRNA}$ ratio at 24 hours $(P=0.0006)$ and at 48 hours $(P=0.01)$ was lower in patients receiving blood transfusion over this period (Figure 2A-H).

Forkhead box P3 (Foxp3) mRNA levels at 24 hours $(P=0.004)$ and at 48 hours $(P=0.02)$ and GATA-binding protein 3 (GATA3) mRNA levels at 24 hours $(P=0.02)$ were lower in those who received blood transfusion in the initial 24 hours postoperatively. IL-10, IFN $\gamma$, T-bet and IL-27 mRNA levels were unrelated to blood transfusion.

The number of units of blood transfused was unrelated to gene expression. 


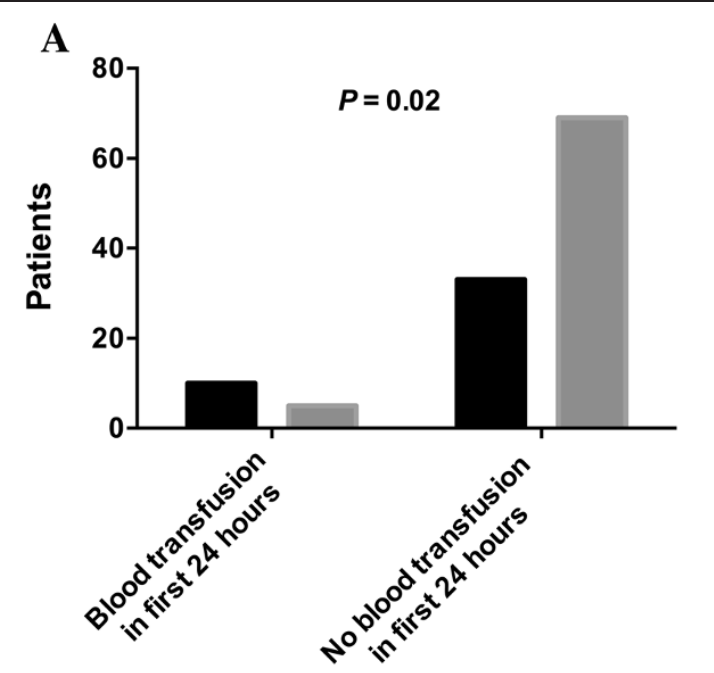

Postoperative infections

No postoperative infections

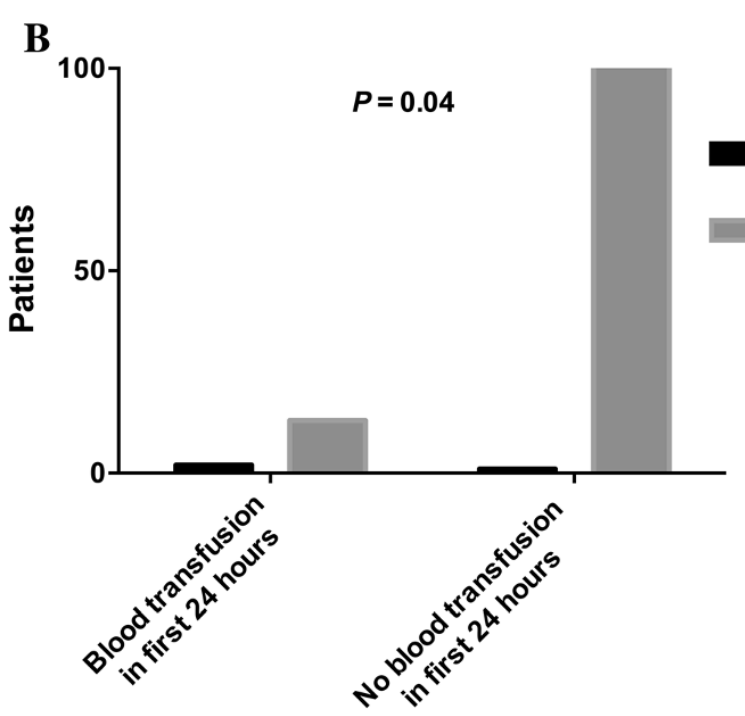

Figure 1 Perioperative blood transfusion, infectious complications and survival. Graph $\mathbf{A}$ represents the proportions of patients developing postoperative infectious complications amongst those patients receiving a blood transfusion in the first 24 hours and in those patients not receiving a blood transfusion during this time period. Graph $\mathbf{B}$ represents the proportions of patients either dying in hospital or surviving to hospital discharge amongst those patients that received a blood transfusion in the first 24 hours (2 patients died out of a total of 15) and in those patients that did not receive a blood transfusion during this time period (1 patient died out of a total of 104).

\section{Mean age of the transfused blood and gene expression}

The age of the blood was calculated as the number of days from collection from a blood donor to transfusion. The mean age of the transfused blood was 23 days (standard deviation 5.9 days, range 11 to 33 days). No association was detected between the mean age of the units of blood transfused and gene expression for any of the selected genes.

\section{Postoperative infections}

Forty-four (37\%) patients developed postoperative infections as an inpatient a median of 9 (IQR 5 to 11) days following the operation. The sites of infection and isolated organisms are shown in Table 4. Patients developing infections stayed longer in hospital (7 (5 to 10) vs. 14 (8 to 19) days, $P<0.0001)$. With the exception of perioperative blood transfusion, a range of demographic and clinical data did not adequately distinguish between those who did and did not develop infection (Table 2).

\section{Inhospital mortality}

Three (2.5\%) patients died in hospital. Age, diabetes, smoking history, ASA, length of operation, cancer diagnosis, planned ICU admission, preoperative immunosuppression or postoperative infections were not associated with inhospital mortality. The requirement for blood transfusion in the first 24 hours postoperatively was associated with a greater mortality $(P=0.04$; Figure $1 \mathrm{~B})$. 


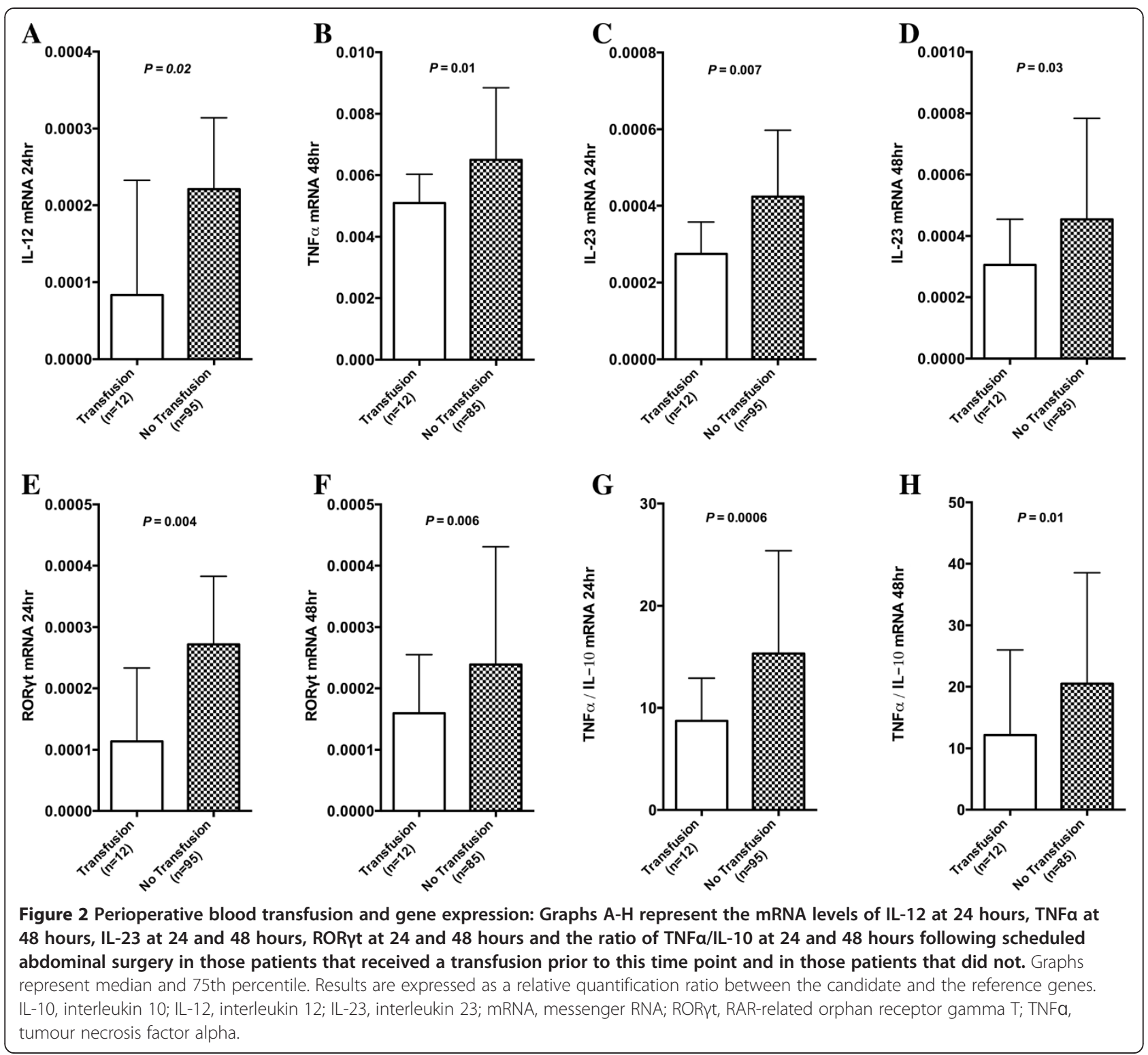

\section{Multivariable analysis}

Selection of variables to be included in the multivariate analysis is described in the Methods section. IL-12, ROR $\gamma$ t, TNF $\alpha /$ IL-10 and Foxp3 mRNA levels at 24 hours along with RORyt, TNF $\alpha /$ IL-10 and Foxp3 mRNA levels at 48 hours were independently associated with transfusion in the first 24 hours (see Additional file 3). There was no independent association between GATA3 and IL-23 mRNA levels at 24 hours and between IL-23 and TNF $\alpha$ mRNA levels at 48 hours and blood transfusion within the first 24 hours.

There was an independent association between the occurrence of infectious complications and the requirement for blood transfusion in the first 24 hours postoperatively (see Additional file 4).

\section{Differential leucocyte count and gene expression}

In order to assess for an association between perioperative variations in white blood cell subpopulations and gene expression, changes in neutrophil, lymphocyte, monocyte and eosinophil counts over the initial 24 hours were compared with changes in individual gene expression over the same period (see Additional file 5). Thirty-six comparisons were generated. Of these, just two attained a level of statistical significance with $P<0.05$ before correcting for multiple comparisons. An association was noted between increasing IL-10 mRNA levels and increasing neutrophil counts $\left(\mathrm{r}^{2}=0.06, P=0.01\right)$ and between decreasing lymphocyte counts and increasing IL-10 mRNA levels $\left(r^{2}=0.05, P=0.02\right)$. 
Table 4 A description of the infectious complications in the postoperative period

\begin{tabular}{|c|c|c|c|}
\hline Infection site & $\begin{array}{l}\text { Number } \\
\text { of } \\
\text { episodes }\end{array}$ & Organisms & $\begin{array}{l}\text { Median time to } \\
\text { development of } \\
\text { infection (days) }\end{array}$ \\
\hline \multirow{7}{*}{$\begin{array}{l}\text { Bloodstream } \\
\text { infection }\end{array}$} & \multirow[t]{7}{*}{11} & Escherichia coli (4) & \multirow[t]{7}{*}{$17(6-28)$} \\
\hline & & ESBL E. coli (1) & \\
\hline & & $\begin{array}{l}\text { E. coli + Enterococcus } \\
\text { faecium (1) }\end{array}$ & \\
\hline & & E. faecium (1) & \\
\hline & & Klebsiella pneumoniae (1) & \\
\hline & & Staphylococcus aureus (1) & \\
\hline & & $\begin{array}{l}\text { Pseudomonas } \\
\text { aeruginosa (2) }\end{array}$ & \\
\hline \multirow[t]{5}{*}{ Pneumonia } & \multirow[t]{5}{*}{9} & Culture negative (5) & \multirow[t]{5}{*}{$7(4-16)$} \\
\hline & & Candida glabrata (1) & \\
\hline & & K. pneumoniae (1) & \\
\hline & & $\begin{array}{l}\text { Organism of the } \\
\text { coliform group (1) }\end{array}$ & \\
\hline & & $\begin{array}{l}\text { Stenotrophomonas } \\
\text { maltophilia (1) }\end{array}$ & \\
\hline \multirow{10}{*}{$\begin{array}{l}\text { Wound } \\
\text { infection }\end{array}$} & \multirow[t]{10}{*}{24} & Culture negative (11) & \multirow[t]{10}{*}{$10(4-14)$} \\
\hline & & Bacteroides fragilis (1) & \\
\hline & & E. coli (4), & \\
\hline & & ESBL E. coli (1) & \\
\hline & & Mixed anaerobes (1) & \\
\hline & & $\begin{array}{l}\text { Organism of the } \\
\text { coliform group (2) }\end{array}$ & \\
\hline & & $\begin{array}{l}\text { Organism of the } \\
\text { coliform group }+ \\
\text { E. faecalis (1) }\end{array}$ & \\
\hline & & $\begin{array}{l}\text { Organism of the } \\
\text { coliform group }+ \\
\text { MRSA (1) }\end{array}$ & \\
\hline & & $\begin{array}{l}\text { Organism of the } \\
\text { coliform group }+ \\
\text { S. aureus (1) }\end{array}$ & \\
\hline & & $P$. aeruginosa (1) & \\
\hline \multirow{7}{*}{$\begin{array}{l}\text { Urinary tract } \\
\text { infection }\end{array}$} & \multirow[t]{7}{*}{15} & Candida albicans (1) & \multirow[t]{7}{*}{$8(6-12)$} \\
\hline & & Culture negative (2) & \\
\hline & & E. coli (6) & \\
\hline & & ESBL E. coli (1) & \\
\hline & & Mixed growth (2) & \\
\hline & & $\begin{array}{l}\text { Organism of the } \\
\text { coliform group (2) }\end{array}$ & \\
\hline & & $P$. aeruginosa (1) & \\
\hline \multirow{5}{*}{$\begin{array}{l}\text { Intra-abdominal } \\
\text { infection }\end{array}$} & \multirow[t]{5}{*}{17} & Culture negative (6) & \multirow[t]{5}{*}{$9(7-14)$} \\
\hline & & E. coli (2) & \\
\hline & & E. coli + E. faecium (1) & \\
\hline & & ESBL E. coli + VRE (1) & \\
\hline & & E. faecalis (1) & \\
\hline
\end{tabular}

Table 4 A description of the infectious complications in the postoperative period (Continued)

E. faecium +
Candida albicans (1)
C. albicans (1)
Enterobacter cloacae (1)
E. cloacae + Organism
of the coliform
group (1)
E. aerogenes +
P. aeruginosa (1)
VRE (1)
K. pneumoniae (1)
Organism of the (3-27)
coliform group (1)
Varicella zoster
virus (VZV)

Data refer to the number of episodes of infection from a particular site. Some patients may have more than one episode of infection. The number in parenthesis in the 'organisms' column the number of episodes of infection attributable to that organism. Data are described as median and interquartile range. ESBL, extended-spectrum beta-lactamase; MRSA, methicillin-resistant Staphylococcus aureus; VRE, vancomycin-resistant Enterococcus.

\section{Discussion}

In this study we determined levels of mRNA for a panel of interlinked cytokines and related transcription factors and demonstrated that those patients receiving a perioperative blood transfusion following major gastrointestinal surgery displayed a pattern of gene expression consistent with greater immunosuppression when compared with a cohort not receiving a blood transfusion. This observation was independent of variables descriptive of the extent of surgical trauma. The gene expression data presented suggests that blood transfusion in this setting may be associated with specific immune defects in innate immunity and in $T_{h} 1$ and $\mathrm{T}_{\mathrm{h}} 17$ pathways. These patients also had an excess of postoperative infectious complications when compared with patients that did not receive a blood transfusion; an observation that was again independent of the duration of the surgical procedure.

The genes selected as candidates in this study are well described as surrogate measures of the specific immune pathways outlined in Table $1[10,11,16]$. Furthermore, the construction of a ratio of gene expression that incorporates the prototypical proinflammatory cytokine, TNF $\alpha$, and the archetypal anti-inflammatory cytokine, IL-10, permits the concurrent assessment of both major facets of the immune response and has previously been utilised to predict postoperative outcome [17]. Whilst the observed reductions in TNF $\alpha$ and IL-12 gene expression are indicative of impaired innate immunity and $\mathrm{T}_{\mathrm{h}} 1$ pathways respectively and the reduction in IL-23 and RORyt is indicative of reduced $T_{h} 17$ activity, these data should not be interpreted as being conclusive. Flow cytometry experiments would be necessary to 
confirm these initial data but present significant logistical barriers and are ideally not performed on stored samples [18]. The $T_{h} 1$ pathway is an essential link between innate and adaptive immunity and $\mathrm{T}_{\mathrm{h}} 1$ effector cells are particularly important for effective bactericidal activity against intracellular pathogens [19]. $\mathrm{T}_{\mathrm{h}} 17$ cells are a branch of the adaptive immune system and appear to deal primarily with organisms inadequately subdued by $T_{h} 1$ or $T_{h} 2$ immunity and that seem to require a very robust inflammatory response [20]. It is biologically plausible that an acquired immune deficit involving these pathways could lead to an increased susceptibility to opportunistic infections with the pathogens encountered in the perioperative period.

Although numerous small studies have suggested that perioperative allogenic blood transfusion may induce immune modulations that create an environment that promotes both microbial growth and tumorigenesis their conclusions are limited by small cohort size, in vitro and ex vivo assays and insensitive protein assays [3,21-26]. In addition, these studies largely predate the routine leukodepletion of transfused blood and suggest a causal relationship between immune modulation and the infusion of allogeneic leukocytes; a biological effect that could be ameliorated by pre-storage leukodepletion [22]. It cannot therefore be inferred that a similar immunological response will be observed following exposure to a leukodepleted product. In contrast, the packed red cells transfused in the study reported here were universally leukodepleted. Furthermore, the use of qRT-PCR in this study to assay gene expression allows for a validated ultrasensitive technique to assess immune pathways in the in vivo state [8-11]. The results we present suggest that the immunosuppression observed following perioperative transfusion may not be solely dependent on the presence of allogeneic leukocytes in the transfused blood. However, despite a $3 \mathrm{log}$ reduction in leukocyte numbers achieved following current filtration techniques some leukocytes do persist and these retain the ability to influence host immune responses [22].

Recently, using a similar methodology we described an excess of infectious complications amongst severely injured trauma patients receiving leukodepleted blood transfusion in conjunction with a gene expression profile characterised by specific deficits in $\mathrm{T}_{\mathrm{h}} 1$ and $\mathrm{T}_{\mathrm{h}} 17$ pathways [7]. The similarities between these results are notable given that there were important differences in the patient populations. The trauma cohort were younger (median age 41), had a higher incidence of early blood transfusion (64\%) and received greater volumes of PRBCs within the initial 24 hours (median 4 units) in conjunction with additional blood products. In addition, the trauma cohort are likely to have endured a greater physiological insult given a higher mortality rate $(19 \%)$ and also a greater incidence of nosocomial infections (63\%). Clearly, patients that receive a blood transfusion outside of the context of a randomised controlled trial will differ from those that do not require transfusion and it is important to attempt to control for these factors. In the previously reported trauma cohort the described observations were independent of the severity of injury and degree of shock at presentation [7]. Similarly, in this perioperative cohort, although on univariate analysis there was a trend towards longer and therefore potentially more complicated surgery being associated with postoperative infections and to a lesser degree with blood transfusion, a multivariable analysis confirmed that the association between blood transfusion and both infectious complications and gene expression patterns were independent of the duration of surgery. Although we describe an association between blood transfusion, an immunosuppressive pattern of gene expression and excess infectious complications, it may be that, despite adjustment for known confounders, the need for blood transfusion is a surrogate marker of severity of surgical stress or an unmeasured premorbid condition and thus a causative role in postoperative immune phenotype is suggested but not proven. However, the consistency of these data from two distinct patient populations, post major gastrointestinal surgery patients and trauma patients, strengthens our underlying hypothesis.

The association between blood transfusion and infectious complications in the perioperative period has been well described previously $[2,3,27]$. This association appears to be consistent amongst cohorts that received either whole blood or leukodepleted blood. The magnitude of the effect size is potentially quite substantial with one recent estimate quantifying the increased risk of infection at $29 \%$ for each unit of blood transfused [27]. That we were able to describe a similar association between blood transfusion and nosocomial infection in a smaller cohort of patients may be related to this effect size, in addition to the selection of an at-risk population using patient age, gastrointestinal surgery under general anaesthesia and the requirement for inpatient treatment as inclusion criteria. We did not, however, record blood transfusions that were administered following the initial 24 hours postoperatively. The postoperative infection rates we report are consistent with similar patient populations [28]. This study also described an association between blood transfusion and mortality. However, whilst the mortality rate is consistent with similar populations [28], with only three deaths occurring in the cohort as a whole, no conclusions regarding causation should be inferred from this association.

It is unsurprising that we did not observe an association between increasing age of the transfused blood and either perioperative infectious complications or patterns of gene expression as this study was underpowered to detect such an association. There is much current debate surrounding the potential pathogenicity associated with blood stored for excessive periods prior to transfusion. In the perioperative 
period, blood stored for longer periods has been linked to an excess of infectious complications [29-31]. The results of a randomised controlled trial comparing blood stored for under a week with older blood in intensive care patients are awaited and will provide important and relevant data [32].

\section{Conclusions}

Our data suggest that the transfusion of leukodepleted allogeneic blood during or immediately after major gastrointestinal surgery is associated with patterns of gene expression consistent with immunosuppression and specific deficiencies in innate immunity and $T_{h} 1$ and $T_{h} 17$ proinflammatory immune pathways. A mechanistic link between allogenic perioperative blood transfusion, defects in essential bactericidal pathways and an excess of nosocomial infections is suggested but not proven. Further research is necessary in order to prove causation.

\section{Key messages}

- Perioperative blood transfusion is associated with an excess of nosocomial infections.

- Perioperative blood transfusion is associated with a specific gene expression profile indicative of immune suppression that could predispose patients to nosocomial infections.

\section{Additional files}

Additional file 1: Antibiotic prophylaxis for Gl surgery in adults. Institutional guidelines for perioperative antibiotic prophylaxis in adult patients undergoing gastrointestinal surgery.

Additional file 2: Criteria used for defining the sites of infection. Criteria used for defining the infection sites based on the Center for Disease Control and Prevention definitions [13].

Additional file 3: Multivariable linear regression analysis for prediction of gene expression. Multivariable linear regression analysis of gene expression using requirement for blood transfusion, diagnosis of cancer, duration of the surgical procedure, age, ASA class and the presence of preoperative immunosuppression transfusion as potential independent variables. Selection of variables is described in the Methods section.

Additional file 4: Multivariable logistical regression analysis for postoperative infections. Multivariable logistical regression analysis of postoperative infections using cancer diagnosis, duration of surgery and transfusion with the first 24 hours postoperatively as independent variables. Selection of variables is described in the Methods section.

Additional file 5: A comparison of changes in leucocyte subpopulations with changes in candidate gene expression. Changes in leucocyte subpopulations over the perioperative period are expressed by calculating a ratio of the cell count at 24 hours to the preoperative cell count. The same calculation was used to assess the change in gene expression over the same period.

\section{Abbreviations}

ASA: American Society of Anesthesiology; B2M: $\beta 2$ microglobulin (B2M); CDNA: complementary DNA; Ct: cycle threshold; Foxp3: forkhead box P3 (FOXP3); GATA3: GATA-binding protein 3 (GATA3); ICU: intensive care unit; IFNY: interferon gamma (IFNG); IL: interleukin; IL-10: interleukin 10 (IL 10); IL-12: interleukin 12 (IL 12A); IL-23: interleukin 23 (IL23A); IL-27: interleukin 27
(IL27); IQR: interquartile range; MHC: major histocompatibility complex; mRNA: messenger RNA; PRBC: packed red blood cells; qRT-PCR: quantitative real-time polymerase chain reaction; RORyt: RAR-related orphan receptor gamma $\mathrm{T}(R O R C)$; RT-PCR: real-time polymerase chain reaction;

SAGM: sodium chloride, adenine, glucose, mannitol; $T_{h}$ : T-helper cell; $T_{h}$ : T-helper cell type $1 ; T_{h} 17$ : T-helper cell type $17 ; T_{h} 2$ : T-helper cell type 2 ; TNFa: tumour necrosis factor alpha (TNF); $T_{\text {reg: }}$ T regulatory cell; UBC: ubiquitin C (UBC)

\section{Competing interests}

The authors declare that they have no competing interests.

\section{Authors' contributions}

PCF contributed to the data collection, laboratory analysis, and manuscript preparation. HDTT contributed to the data analysis, laboratory analysis, and manuscript preparation. RMP contributed to the study design, patient recruitment, and manuscript preparation. GLA contributed to the study design, patient recruitment, and manuscript preparation. JRP contributed to the data analysis, and manuscript preparation. HCO contributed to the laboratory analysis, data analysis, and manuscript preparation. $\mathrm{CJH}$ contributed to the study design, data analysis, and manuscript preparation. MJO'D contributed to the study design, patient recruitment, data analysis, and manuscript preparation. All authors read and approved the final manuscript.

\section{Acknowledgements}

The authors are grateful to the Adult Critical Care Research Team of the Royal London Hospital, Barts Health NHS Trust for data collection and blood sampling and to Dr Charles A Mein DPhil, Genome Centre, William Harvey Research Institute, Charterhouse Square, Barts and the London School of Medicine and Dentistry for his technical advice and assistance.

\section{Funding}

This study was supported by a grant from the National Institute of Academic Anaesthesia (British Journal of Anaesthesia / Royal College of Anaesthetists Project Grant).

\section{Author details}

${ }^{1}$ Adult Critical Care Unit, Royal London Hospital, Barts Health NHS Trust, Whitechapel Road, London E1 1BB, UK. ${ }^{2}$ Centre for Translational Medicine and Therapeutics, William Harvey Research Institute, Barts and the London School of Medicine and Dentistry, Queen Mary University of London, Charterhouse Square, London EC1M 6BQ, UK. ${ }^{3}$ Department of Medicine, Wolfson Institute for Biomedical Research, University College London, Cruciform Building, Gower Street, London WC1E 6BT, UK.

Received: 29 June 2014 Accepted: 9 September 2014 Published online: 01 October 2014

\section{References}

1. Opelz G, Terasaki PI: Improvement of kidney-graft survival with increased numbers of blood transfusions. N Engl J Med 1978, 299:799-803.

2. Cata JP, Wang H, Gottumukkala V, Reuben J, Sessler DI: Inflammatory response, immunosuppression, and cancer recurrence after perioperative blood transfusions. Br J Anaesth 2013, 110:690-701.

3. Jensen LS, Andersen AJ, Christiansen PM, Hokland P, Juhl CO, Madsen G, Mortensen J, Møller-Nielsen C, Hanberg-Sørensen F, Hokland M: Postoperative infection and natural killer cell function following blood transfusion in patients undergoing elective colorectal surgery. Br J Surg 1992, 79:513-516.

4. Pearse RM, Moreno RP, Bauer P, Pelosi P, Metnitz P, Spies C, Vallet B, Vincent JL, Hoeft A, Rhodes A, European Surgical Outcomes Study (EuSOS) group for the Trials groups of the European Society of Intensive Care Medicine and the European Society of Anaesthesiology: Mortality after surgery in Europe: a 7 day cohort study. Lancet 2012, 380:1059-1065.

5. Baron DM, Hochrieser H, Posch M, Metnitz B, Rhodes A, Moreno RP, Pearse RM, Metnitz P, for the European Surgical Outcomes Study (EuSOS) group for the Trials Groups of the European Society of Intensive Care Medicine and the European Society of Anaesthesiology: Preoperative anaemia is associated with poor clinical outcome in non-cardiac surgery patients. Br J Anaesth 2014, 113:416-423. in press. 
6. Lapierre $V$, Aupérin A, Tiberghien P: Transfusion-induced immunomodulation following cancer surgery: fact or fiction? J Natl Cancer Inst 1998, 90:573-580.

7. Torrance HD, Brohi K, Pearse RM, Mein CA, Wozniak E, Prowle JR, Hinds CJ, O'Dwyer MJ: Association, between gene expression biomarkers of immunosuppression and blood transfusion in severely injured polytrauma patients. Ann Surg 2014 [Epub ahead of print]

8. O'Dwyer MJ, Mankan AK, Stordeur P, O'Connell B, Duggan E, White M, Kelleher DP, McManus R, Ryan T: The occurrence of severe sepsis and septic shock are related to distinct patterns of cytokine gene expression. Shock 2006, 26:544-550.

9. O'Dwyer MJ, Mankan AK, Ryan AW, Lawless MW, Stordeur P, Kelleher D, McManus R, Ryan T: Characterization of tumour necrosis factor-alpha genetic variants and mRNA expression in patients with severe sepsis. Int J Immunogenet 2008, 35:279-285.

10. White M, Martin-Loeches I, Lawless MW, O'Dwyer MJ, Doherty DG, Young V, Kelleher D, McManus R, Ryan T: Hospital-acquired pneumonia after lung resection surgery is associated with characteristic cytokine gene expression. Chest 2011, 139:626-632.

11. Pachot A, Monneret $G$, Voirin N, Leissner P, Venet F, Bohé J, Payen D, Bienvenu J, Mougin B, Lepape A: Longitudinal study of cytokine and immune transcription factor mRNA expression in septic shock. Clin Immunol 2005 114:61-69.

12. Dripps RD, Lamont A, Eckenhoff JE: The role of anesthesia in surgical mortality. JAMA 1961, 178:261-266.

13. Horan TC, Andrus M, Dudeck MA: CDC/NHSN surveillance definition of health care-associated infection and criteria for specific types of infections in the acute care setting. Am J Infect Control 2008, 36:309-332.

14. Vandesompele J, De Preter K, Pattyn F: Accurate normalization of real-time quantitative RT-PCR data by geometric averaging of multiple internal control genes. Genome Biol 2002, 3:0034.1-0034.11. research0034.

15. Livak K, Schmittgen TD: Analysis of relative gene expression data using real-time quantitative PCR and the 2(-Delta Delta C(T)) Method. Methods 2001, 25:402-408.

16. Monneret G, Venet F, Pachot A, Lepape A: Monitoring immune dysfunctions in the septic patient: a new skin for the old ceremony. Mol Med 2008, 14:64-78.

17. Duggan E, Caraher E, Gately K, O'Dwyer M, McGovern E, Kelleher D, McManus R, Ryan T: Tumor necrosis factor-alpha and interleukin-10 gene expression in peripheral blood mononuclear cells after cardiac surgery. Crit Care Med 2006, 34:2134-2139.

18. Maecker HT, McCoy JP, Nussenblatt P: Standardizing immunophenotyping for the Human Immunology Project. Nat Rev Immunol 2012, 12:191-200.

19. Kitamura N, Kaminuma O, Mori A, Hashimoto T, Kitamura F, Miyagishi M, Taira K, Miyatake S: Correlation between mRNA expression of Th1/Th2 cytokines and their specific transcription factors in human helper T-cell clones. Immunol Cell Biol 2005, 83:536-541.

20. Korn T, Bettelli E, Oukka M, Kuchroo VK: IL-17 and Th17 cells. Annu Rev Immunol 2009, 27:485-517.

21. Van Twuyver E, Mooijaart RJ, Ten Berge IJ, Van der Horst AR, Wilmink JM, Kast WM, Melief CJ, de Waal LP: Pretransplantation blood transfusion revisited. N Engl J Med 1991, 325:1210-1213.

22. Blajchman MA: Immunomodulation and blood transfusion. Am J Ther 2002 9:389-395.

23. Kirkley SA, Cowles J, Pellegrini VD, Harris CM, Boyd AD, Blumberg N: Blood transfusion and total joint replacement surgery: T helper 2 (TH2) cytokine secretion and clinical outcome. Transfus Med 1998, 8:195-204.

24. Waymack JP, Gallon L, Barcelli U, Alexander JW: Effect of blood transfusions on macrophage function in a burned animal model. Curr Surg 1986, 43:305-307.

25. Decker D, Schondorf M, Bidlingmaier F, Hirner A, von Ruecker AA: Surgical stress induces a shift in the type-1/type-2 T-helper cell balance, suggesting down-regulation of cell-mediated and up-regulation of antibody-mediated immunity commensurate to the trauma. Surgery 1996, 119:316-325.

26. Nielsen $\mathrm{HJ}$, Hammer JH, Moesgaard F, Kehlet $\mathrm{H}$ : Comparison of the effects of SAG-M and whole-blood transfusions on postoperative suppression of delayed hypersensitivity. Can J Surg 1991, 34:146-150.

27. Horvath KA, Acker MA, Chang H, Bagiella E, Smith PK, Iribarne A, Kron IL, Lackner P, Argenziano M, Ascheim DD, Gelijns AC, Michler RE, Van Patten D, Puskas JD, O'Sullivan K, Kliniewski D, Jeffries NO, O'Gara PT, Moskowitz AJ, Blackstone $\mathrm{EH}$ : Blood transfusion and infection after cardiac surgery. Ann Thorac Surg 2013, 95:2194-2201.
28. Pearse RM, Harrison DA, MacDonald N, Gillies MA, Blunt M, Ackland G, Grocott MP, Ahern A, Griggs K, Scott R, Hinds CJ, Rowan K, OPTIMISE Study Group: Effect of a perioperative, cardiac output-guided hemodynamic therapy algorithm on outcomes following major gastrointestinal surgery: a randomized clinical trial and systematic review. JAMA 2014, 311:2181-2190.

29. Vamvakas EC, Carven JH: Transfusion and postoperative pneumonia in coronary artery bypass graft surgery: effect of the length of storage of transfused red cells. Transfusion 1999, 39:701-710.

30. Leal-Noval SR, Jara-López I, García-Garmendia JL, Marín-Niebla A, Herruzo-Avilés A, Camacho-Laraña P, Loscertales J: Influence of erythrocyte concentrate storage time on postsurgical morbidity in cardiac surgery patients. Anesthesiology 2003, 98:815-822

31. Mynster T, Nielsen HJ: The impact of storage time of transfused blood on postoperative infectious complications in rectal cancer surgery. Danish RANX05 Colorectal Cancer Study Group. Scand J Gastroenterol 2000, 35:212-217.

32. Lacroix J, Hébert P, Fergusson D, Tinmouth A, Blajchman MA, Callum J, Cook D, Marshall JC, Mclntyre L, Turgeon AF, ABLE study group: The Age of Blood Evaluation (ABLE) randomized controlled trial: study design. Transfus Med Rev 2011, 25:197-205.

doi:10.1186/s13054-014-0541-x

Cite this article as: Fragkou et al:: Perioperative blood transfusion is associated with a gene transcription profile characteristic of immunosuppression: a prospective cohort study. Critical Care 2014 18:541.

\section{Submit your next manuscript to BioMed Central and take full advantage of:}

- Convenient online submission

- Thorough peer review

- No space constraints or color figure charges

- Immediate publication on acceptance

- Inclusion in PubMed, CAS, Scopus and Google Scholar

- Research which is freely available for redistribution 